\title{
Effect of non genetic factors on productive traits of Black Bengal goats
}

\author{
Zinat Mahal ${ }^{1}$, M. A. M. Y. Khandoker ${ }^{2}$ and M. N. Haque ${ }^{3^{*}}$ \\ ${ }^{1}$ Ministry of Fisheries and Livestock, Bangladesh Secretariat, Dhaka-1000, Bangladesh, ${ }^{2}$ Department of Animal \\ Breeding and Genetics, Bangladesh Agricultural University, Mymensingh-2202, Bangladesh and ${ }^{3}$ Department of \\ Animal Breeding and Genetics, Sylhet Agricultural University, Sylhet, Bangladesh, *Email: nazmulabg@gmail.com
}

\begin{abstract}
Accumulated five years data on 197 kids of 15 Black Bengal bucks in the nucleus breeding flock of Black Bengal goats were analyzed for the study of production traits. The traits considered were birth weight, weight at every 3month interval up to 12-month, semen characteristics and milk yield. Semen parameters were evaluated from 450 ejaculates of 15 Black Bengal bucks collected twice a week by artificial vagina method and daily milk yield of Black Bengal goats were estimated from the analysis of 57 lactation records of 30 does. The significance of fixed effects sex of kid, parity, litter size, season, age, body weight and scrotal circumferance were analyzed using least-squares analyses of variance of the general linear model (GLM) procedure of the Statistical Analysis System (SAS, 1998). Least-squares means for body weights at birth, 3, 6, 9 and 12-month of age were 1.3, 4.8, 8.0, 11.1 and $14.0 \mathrm{~kg}$, respectively. Body weights at 3,6, 9 and 12-month of age except at birth were affected by the sex of kids $(p<0.05)$. Type of birth and parity of dam had the significant affect $(p<0.05)$ on birth weight, whereas season of birth had significant $(p<0.05)$ effect on the body weight. The least-squares means of semen volume (ml/ejaculate), sperm concentration $\left(10^{9} / \mathrm{ml}\right)$, mass motility $(\%)$, live spermatozoa $(\%)$ and normal spermatozoa $(\%)$ were $0.5,2.4,80.0$, 86.5 and 89.3 , respectively. Age of bucks had significant $(p<0.01)$ affect on semen volume, sperm concentration. Body weight had a significant $(p<0.05)$ effect on semen volume only. Least-squares mean of daily milk yield was 379.9 lit.. Milk yields was significantly $(p<0.01)$ affected by litter size and season of kidding. It is suggested that nongenetic factors should be adopted as a technique for improving the productive traits.
\end{abstract}

Keywords: Black Bengal, Growth traits, Milk yield, Semen parameters, Traits

\section{Introduction}

The goal of a livestock system including goats is to produce a quantity of quality products with maximum efficiency. A component in achieving this goal is to improve the goat genetically in the areas of quantity, quality and efficiency. Genetic improvement can be achieved by selection where effect of non genetic factors on productive traits is most important and should be considered at first. Knowledge about environmental factors on economic traits is essential for the production of goats that means it is possible to improve birth weight, body weight gain and milk yield of does, which in turn may cause to reduce kid mortality to the reasonable extent and increasing overall production potential (Husain, 2004).

Therefore, the objective of this study was to examine the effects of different non genetic factors on the production performance of Black Bengal goats in Bangladesh.

\section{Materials and Methods}

\section{Location}

The study was conducted in the nucleus breeding flock at the Artificial Insemination Center under the Department of Animal Breeding and Genetics, Bangladesh Agricultural University, Mymensingh with the financial support of the USDA project entitled "Conservation of Black Bengal Goat as the Potential Genetic Resource in Bangladesh" during the period from January, 2010 to June, 2012. 


\section{Animal Management}

Animals were managed and raised under confinement as an intensive system. They were housed in individual pens $(4 \times 2.5 \mathrm{sq} . \mathrm{ft})$ in a galvanized iron sheet shed with a wooden slatted floor raised above the ground level. The house was provided with necessary arrangements for feeding and watering and for sufficient access to fresh air. Semen was collected by Artificial Vagina method and semen was frozen by reducing temperature gradually (Hussain, 2004). The bucks used in this experiment were kept under zero grazing management and stall fed twice daily on a diet consisting of Napier, German and/or Maize fodder ad labium. The feed was supplemented with commercial (Surma Feed, BRAC Feed Mill, Sreepur, Gazipur) pellet in two meals twice in a day @ $100 \mathrm{gm} /$ buck. They were allowed for grazing and exercise for 1 to 2 hours daily. The breeding bucks were supplied germinated gram (20gm/buck/day). Clean and safe water was made available at all the time. Throughout this study, almost identical ration was provided for each of the bucks. All bucks were vaccinated against Peste des Petits Ruminants (PPR) and dewormed routinely. The animals were identified with neckband tags. The identities of newborns and their parents, date of birth, sex of kid, type of birth and parity of dam were recorded. For each individual a record sheet with full details of each parameter along with pedigree information were maintained. Newborn kids were allowed to suckle their mothers and were left with them up to 3 months of age. Kids were weaned at three month of age. Following weaning, kids were offered 50-100 g/head/day of the same commercial concentrate. All the female kids were kept in shed with their dams, but males over 3 months of age were housed separately in individual pen $(4 \times 2.5 \mathrm{sq} . \mathrm{ft})$ to avoid uncontrolled breeding. No castration was performed on the male kids.

\section{Data collection}

A total of 197 Black Bengal progeny of 15 Black Bengal Bucks of were 19 to 34 months in age. The bucks were between. The body weight and scrotal circumference (SC) of bucks were 19.0 to $25.0 \mathrm{~kg}$ and 17.0 to $22.0 \mathrm{~cm}$ respectively. Data on body weights and semen characteristics of individual animals were recorded at a regular basis (Mia, 1997). The milk yield were recorded fortnightly.

\section{Traits analyzed}

The traits analyzed were growth traits (birth, 3, 6, 9 and 12-month body weight), semen characteristics (semen volume, sperm concentration, mass motility, sperm livability and normal spermatozoa) and milk yield of progeny.

\section{Statistical analysis}

The significance of fixed effects was tested conducting least-squares analyses of variance using the general linear model (GLM) procedure of the Statistical Analysis System (SAS, 1998) according to the following liner model:

For growth performance: $Y_{i j k l m}=\mu+S_{i}+M_{j}+R_{k}+T_{1}+E_{i j k l m}$

where $Y_{i j k l m}$ is the body weight at different ages (individual animal record for the trait), $\mu$ is the overall mean, $S_{i}$ is the fixed effect of $i^{\text {th }}$ sex of kid, $M_{j}$ is the fixed effect of $j^{\text {th }}$ type of birth, $R_{k}$ is the effect of $k^{\text {th }}$ parity of dam, $T_{1}$ is the effect of $I^{\text {th }}$ season of birth and $E_{i j k l m}$ is the residual error. Sex of kid was grouped into male and female. The year was divided into three seasons; winter (November to February), summer (March to June) and rainy (July to October). Number of kid born was grouped into single, twins and triplets. Parity of dam was grouped into first, second, third and fourth parities.

For semen characteristics: $Y_{i j k l m}=\mu+S_{i}+M_{j}+R_{k}+E_{i j k l m}$

Where $Y_{i j k l m}$ is the semen characteristics, $\mu$ is the overall mean, $S_{i}$ is the fixed effect of $i^{\text {th }}$ age, $M_{j}$ is the fixed effect of the $j^{\text {th }}$ body weight, $R_{k}$ is the effect of $k^{\text {th }}$ scrotal circumference and $E_{i j k l m}$ is the residual error. Age of bucks was grouped into classes of 7-9 and $>9-12$ months. Body weight of bucks was grouped into classes of 10-15 and >15-20 and kg. Scrotal circumference of bucks ranges from $16-20 \mathrm{~cm}$. 
For milk yield: $Y_{i j k}=\mu+S_{i}+M_{j}+E_{i j k}$

Where $Y_{i j k}$ is the dependent variable, $\mu$ is the overall mean, $S_{i}$ is the fixed effect of $i^{\text {th }}$ season of kidding, $M_{j}$ is the fixed effect of the $\mathrm{j}^{\text {th }}$ litter size and $\mathrm{E}_{\mathrm{ijk}}$ is the residual error. The year was divided into three seasons; winter (November to February), summer (March to June) and rainy (July to October). The significant means were separated using the Duncan's multiple range test.

\section{Results and Discussion}

\section{Growth performance}

Least-squares means with standard errors of Black Bengal progeny's growth performance were affected by various factors (Table 1). The male kids were heavier than females from birth to 12-month of age, and the differences between the two sexes were significant at all ages except at birth. Sex had a significant effect on growth at weaning to until growing adult. This was in conformity with the reports of Husain et al. (1996) and Akhter et al. (2000) who reported that due to hormonal and environmental causes male kids were heavier than female. Consistent superiority of male lambs has been widely reported (Matika et al., 2003). Singh (1997) reported significant effect of sex on body weights at 3,6, 9 and 12-month of age. Husain et al. (1996) observed significant effect of sex on body weights at birth, 3, 6, 9 and 12 months of age of Black Bengal goat under extensive system. On the other hand Figueiredo et al. (1982) and Khan and Sahni (1983) did not find differences between the sexes for birth weight in goats. In this study, males were significantly heavier and grew faster from weaning onward, implying that sex effects are more pronounced with age after puberty. These have been attributed to hormonal differences between sexes and their resultant effects on growth. The effect of number of kids born was significant $(p<0.01)$ on the body weight at birth only. Single-born kids had a heavier weight at birth than multiple kidding, whilst no significant differences were found between twin and triplet kids. These results agree with the results of Husain et al. (1996) and Akhter et al. (2000). Single-born kids were 1.8\% heavier at birth compared to average weight of kids born as twins and $44.1 \%$ more heavily than those born as triplet. The lower birth weight with increasing litter size have been reported by Wilson (1958) and Mia and Bhuiyan, (1997). Mukundan et al. (1982) has shown that much of the variation in birth weight was associated with type of birth where single kids were heavier than multiple born kids. Lower body weights in triplets till weaning might be due to less nutrition to their kids during prenatal and suckling period.

On contrary, Mittal (1979) did not find a significant effect of number of birth on birth weights although single kid heavier than those born in multiple births. Singh et al. (1990) noticed that birth weight of single born kids was highest followed by twins and triplets but the difference study were not significant in the local and crossbred kids.

This difference is probably due to the intrauterine environment where a higher availability of nutrients to the single kid, lack of competition as well as more space may facilitate growth. The uterine space and available nutrient shared by more than one kid may be responsible for the reduced birth weight with increasing litter size.

Parity of dam significantly $(p<0.05)$ influenced birth weight only. Birth weight increased with parity. Significantly highest birth weight was observed in $4^{\text {th }}$ parity $(1.5 \pm 0.1)$ and lowest in $1^{\text {st }}$ parity $(1.1 \pm 0.1)$. The difference in birth weight between $1^{\text {st }}$ and $2^{\text {nd }}$ parity was not significant.

Parity of dam significantly $(p<0.05)$ influenced birth weight only. Significantly highest birth weight was in $4^{\text {th }}$ parity $(1.5 \pm 0.1)$ and lowest in $1^{\text {st }}$ parity $(1.1 \pm 0.1)$ (Table 1$)$. Wilson (1958) found that the effect of age of dam was significant on birth weight and growth rate at pre-weaning and those young ewes that has the tendency to produce smaller progenies at birth.

Husain et al. (1996) observed no significant effect of parity of dam on body weights at birth, 3, 6, 9 and 12-month of age of Black Bengal goat under extensive system. The effect of parity of dam on kids is thus imparted as maternal influence whose direct influence is limited to the nursing period. At different stages 
of growth the variation in body weights due to season of birth was significant $(p<0.05)$. Winter born kids were significantly heavier at birth to 12 months of age than other seasons. At different stages of growth the variation in body weights $(B W)$ due to season of birth was significant $(p<0.05)($ Table 1). The effect of season may be explained partly by the climatic conditions, hence, feeding practices in different seasons for dams and offspring were similar. Important influence of season on kid live weights have been reported in several breeds (Warmington and Kirton, 1990; Hermiz et al., 1997). But Singh (1997) observed significant effect of season of birth on body weights at 3 and 6-month of age whereas no significant effect at 9 and 12-month of age in Boar goats. Season of birth plays an important role in growth performance indirectly through its influence on the dam's nutrition and hence amount of milk available to the unweaned kids. In the post-weaning period its influence is related to its effect on the quality and quantity of pasture available to the weaned kids. The lower body weights of rainy season born kids emphasized the need to provide supplementary feed and adequate management for these kids.

Table 1. Progeny growth performance of Black Bengal bucks (Least-squares means with standard errors)

\begin{tabular}{|c|c|c|c|c|c|}
\hline \multirow{2}{*}{ Factors } & \multicolumn{5}{|c|}{ Body weights (kg) at } \\
\cline { 2 - 6 } & Birth & 3-month & 6-month & 9-month & 12-month \\
\hline Sex of kid & NS & ${ }^{*}$ & ${ }^{*}$ & ${ }^{*}$ & $17.9^{\mathrm{a}} \pm 0.7$ \\
\hline Male & $1.3 \pm 0.1$ & $5.2^{\mathrm{a}} \pm 0.6$ & $8.9^{\mathrm{a}} \pm 0.8$ & $13.2^{\mathrm{a}} \pm 0.6$ & $12.1^{\mathrm{b}} \pm 0.5$ \\
\hline Female & $1.2 \pm 0.1$ & $4.5^{\mathrm{b}} \pm 0.6$ & $8.1^{\mathrm{b}} \pm 0.8$ & $10.1^{\mathrm{b}} \pm 0.5$ & $\mathrm{NS}$ \\
\hline Type of birth & ${ }^{*}$ & $\mathrm{NS}$ & $\mathrm{NS}$ & $\mathrm{NS}$ & $16.5 \pm 0.5$ \\
\hline Single & $1.4^{\mathrm{a}} \pm 0.1$ & $5.5 \pm 0.5$ & $8.6 \pm 0.5$ & $12.7 \pm 0.7$ & $13.3 \pm 0.7$ \\
\hline Twins & $1.3^{\mathrm{b}} \pm 0.1$ & $5.3 \pm 0.4$ & $7.7 \pm 0.4$ & $11.1 \pm 0.1$ & $12.1 \pm 1.3$ \\
\hline Triplets & $1.1^{\mathrm{c}} \pm 0.1$ & $4.6 \pm 1.5$ & $7.6 \pm 1.1$ & $9.9 \pm 1.3$ & $\mathrm{NS}$ \\
\hline Parity of dam & ${ }^{*}$ & $\mathrm{NS}$ & $\mathrm{NS}$ & $\mathrm{NS}$ & $14.8 \pm 1.5$ \\
\hline 1st & $1.1^{\mathrm{c}} \pm 0.1$ & $4.4 \pm 0.5$ & $7.7 \pm 0.7$ & $11.5 \pm 0.6$ & $13.6 \pm 1.0$ \\
\hline 2nd & $1.1^{\mathrm{c}} \pm 0.1$ & $5.6 \pm 0.6$ & $8.5 \pm 0.9$ & $11.2 \pm 1.2$ & $12.1 \pm 1.5$ \\
\hline $3^{\text {rd }}$ & $1.3^{\mathrm{b}} \pm 0.1$ & $5.7 \pm 0.7$ & $8.1 \pm 1.0$ & $10.6 \pm 1.3$ & $12.62 \pm 1.93$ \\
\hline $4^{\text {th }}$ & $1.5^{\mathrm{a}} \pm 0.1$ & $6.9 \pm 0.2$ & $8.5 \pm 0.2$ & $10.8 \pm 1.8$ & 12.6 \\
\hline Season of birth & ${ }^{*}$ & ${ }^{*}$ & ${ }^{*}$ & ${ }^{*}$ & \\
\hline Winter & $1.3^{\mathrm{a}} \pm 0.1$ & $5.44^{\mathrm{a}} \pm 0.62$ & $8.5^{\mathrm{a}} \pm 0.7$ & $12.7^{\mathrm{a}} \pm 0.6$ & $15.49^{\mathrm{a}} \pm 0.7$ \\
\hline Summer & $1.3^{\mathrm{b}} \pm 0.1$ & $5.32^{\mathrm{a}} \pm 0.63$ & $8.1^{\mathrm{a}} \pm 0.8$ & $10.1^{\mathrm{b}} \pm 0.5$ & $12.3^{\mathrm{b}} \pm 0.6$ \\
\hline Rainy & $1.217^{\mathrm{c}} \pm 0.057$ & $3.64^{\mathrm{b}} \pm 0.94$ & $5.70^{\mathrm{b}} \pm 1.24$ & $9.69^{\mathrm{b}} \pm 0.32$ & $14.49^{\mathrm{a}} \pm 0.31$ \\
\hline
\end{tabular}

Means with different superscripts in the same column differ significantly. Where, ${ }^{*}(p<0.05) ;{ }^{* *}(p<0.01)$ and NS, Not significant

\section{Semen characteristics}

The effect of age, body weight and scrotal circumference on semen parameters are set out in Table 2 .

All the parameters except mass motility were affected by age. Volume of semen and sperm concentration were increased significantly $(p<0.01)$ with age, however, percentage of live spermatozoa decreased significantly $(p<0.05)$ with age. The percentage of normal spermatozoa was increased significantly $(p<0.05)$ with age.

Body weight had a significant $(p<0.01)$ effect on semen volume but no significant effect on other semen parameters.

Scrotal circumference significantly influenced $(p<0.05)$ all the semen characteristics investigated in the Black Bengal bucks. Semen volume and sperm concentration increased linearly with scrotal circumference. Highest semen volume $(0.6 \mathrm{ml})$ was recorded at the scrotal circumference of $20 \mathrm{~cm}$ and lowest $(0.4)$ at $16 \mathrm{~cm}$. The highest sperm concentration $\left(2.4 \times 10^{9}\right.$ cells $\left./ \mathrm{ml}\right)$ was at the scrotal circumference of $20 \mathrm{~cm}$ and the lowest $\left(2.2 \times 10^{9}\right.$ cells $\left./ \mathrm{ml}\right)$ in $17 \mathrm{~cm}$. 
Table 2. Progeny semen characteristics of Black Bengal bucks (Least squares means with standard errors)

\begin{tabular}{|c|c|c|c|c|c|}
\hline Factors & $\begin{array}{c}\text { Semen } \\
\text { volume }(\mathrm{ml})\end{array}$ & $\begin{array}{c}\text { Sperm } \\
\text { concentration } \\
\text { (million/ml) }\end{array}$ & $\begin{array}{c}\text { Mass } \\
\text { motility (\%) }\end{array}$ & $\begin{array}{c}\text { Sperm } \\
\text { livability (\%) }\end{array}$ & $\begin{array}{c}\text { Normal } \\
\text { sperm (\%) }\end{array}$ \\
\hline Age (months) & ** & ** & NS & * & * \\
\hline $7-9$ & $0.4^{\mathrm{C}} \pm 0.1$ & $2.3^{b} \pm 0.1$ & $78.7 \pm 0.1$ & $88.0^{a} \pm 0.8$ & $87.20^{a} \pm 0.66$ \\
\hline$>9-12$ & $0.54^{b} \pm 0.0$ & $2.6^{b} \pm 0.0$ & $79.6 \pm 0.3$ & $85.2^{\mathrm{ab}} \pm 0.6$ & $89.20^{\mathrm{a}} \pm 0.44$ \\
\hline Body Weight (kg) & ** & NS & NS & NS & NS \\
\hline $10-15$ & $0.40^{\mathrm{C}} \pm 0.0$ & $2.5 \pm 0.1$ & $80.1 \pm 0.7$ & $87.3 \pm 0.9$ & $89.98 \pm 0.66$ \\
\hline$>15-20$ & $0.45^{b} \pm 0.0$ & $2.6 \pm 0.2$ & $79.7 \pm 0.6$ & $87.0 \pm 0.8$ & $89.67 \pm 0.67$ \\
\hline $\begin{array}{c}\text { Scrotal } \\
\text { circumference }(\mathrm{cm})\end{array}$ & ** & $* *$ & $* *$ & $*$ & * \\
\hline 16 & $0.39^{\mathrm{C}} \pm 0.1$ & $2.3^{\mathrm{C}} \pm 0.4$ & $81.1^{a b c} \pm 1.7$ & $89.2^{\mathrm{a}} \pm 3.3$ & $87.5^{\mathrm{b}} \pm 2.8$ \\
\hline 17 & $0.44^{\mathrm{C}} \pm 0.0$ & $2.2^{\mathrm{C}} \pm 0.1$ & $80.6^{a b c} \pm 0.8$ & $85.2^{\mathrm{ab}} \pm 1.4$ & $90.1^{a b} \pm 0.9$ \\
\hline 18 & $0.48^{\mathrm{C}} \pm 0.0$ & $2.3^{c} \pm 0.1$ & $79.4^{\mathrm{bc}} \pm 0.6$ & $83.8^{b} \pm 0.1$ & $88.1^{a b} \pm 0.7$ \\
\hline 29 & $0.46^{\mathrm{C}} \pm 0.0$ & $2.5^{\mathrm{bc}} \pm 0.1$ & $81.7^{\mathrm{ab}} \pm 0.7$ & $86.8^{\mathrm{ab}} \pm 1.0$ & $90.3^{\mathrm{ab}} \pm 0.7$ \\
\hline 20 & $0.57^{\mathrm{b}} \pm 0.0$ & $2.4^{\mathrm{bc}} \pm 0.1$ & $78.8^{\mathrm{C}} \pm 0.9$ & $86.1^{\mathrm{ab}} \pm 1.5$ & $91.1^{\mathrm{a}} \pm 0.9$ \\
\hline
\end{tabular}

Means with different superscripts in the same column differ significantly

Where, ${ }^{*}(p<0.05) ;{ }^{* *}(p<0.01)$ and NS, Not significant

Ejaculate volume and sperm concentration increased with age which is in agreement with the findings of Al-Ghalban et al. (2004) and Salhab et al. (2003). The results agrees with those of Alberio (1976) and Analla et al. (1996), in France sperm concentration increased with the age of lambs, but not with those of Mandiki et al. (1998), who reported that sperm concentration is not affected by the age of lambs.

The percentage of live sperm and normal sperm was affected by age. Osinowo et al. (1988) found no significant differences in percentage between yearlings and mature rams. The occurrence of abnormal sperm head shapes is reportedly higher at younger and older ages than at around the age of sexual maturity (Barth and Oko, 1989; Amann et al., 2000).

In contrast, no differences in terms of major and total sperm defects due to age were reported in bulls (Rodriguez, 2003). Similarly, increased age did not affect sperm abnormalities in bucks in Ethiopia (Roca et al., 1992).

Mature bucks were heavier, with a larger scrotal circumference, semen volume, sperm concentration and the percentage of abnormal sperm were recorded when compared to the yearling bucks.

Body weight had a significant effect on semen volume. Other semen parameters are not affected by body weight (Table 2). The result is in agreement with the findings of Salhab et al. (2003).

Scrotal circumference significantly influenced $(p<0.05)$ all the semen characteristics investigated in the Black Bengal bucks (Table 2). The SC is an important trait that is closely associated with the testicular growth and sperm production capacity of domestic animals. Thus, selecting males based on their SC would result in larger testes, potentially with the capacity to produce more spermatozoa (Daudu, 1984). Being a highly heritable component of fertility, it is important to include SC when evaluating breeding animals (Bailey et al., 1996). The higher SC measurements indicate higher testicular mass and larger sperm production (Furstoss, et al., 2009).

If the scrotal circumference is increased, then semen volume, sperm concentration and even all other semen parameter will be increased. So scrotal circumference is an important factor for buck selection.

\section{Milk yield}

Least squares means and standard errors for Test Day Milk Yield (TDMY) of progeny are shown in Table 3. TDMY was significantly $(P<0.01)$ influenced by the factors litter size and seasons. 
Table 3. Progeny milk yield of Black Bengal goats (Least squares means with standard errors)

\begin{tabular}{|c|c|}
\hline Factors & Test Day Milk Yield (g) \\
\hline Litter size & $308.2^{\mathrm{b}} \pm 25.9$ \\
\hline 1 & $470.0^{\mathrm{a}} \pm 62.0$ \\
\hline 2 & ${ }^{* *}$ \\
\hline Season & $386.3^{\mathrm{b}} \pm 42.2$ \\
\hline Winter & $315.6^{\mathrm{c}} \pm 29.6$ \\
\hline Summer & $419.5^{\mathrm{a}} \pm 71.5$ \\
\hline Rainy &
\end{tabular}

Means with different superscripts in the same column differ significantly Where, ${ }^{* *}(p<0.01)$

Milk yields was significantly $(p<0.01)$ affected by litter size. Milk yields were $308.2 \pm 25.9$ and $470.0 \pm 62.0 \mathrm{~g}$ for the single and multiple litter size, respectively.

Milk yields was significantly $(p<0.01)$ affected by season of kidding. Goats kidded in rainy being the highest yielder $(430.0 \pm 69.3 \mathrm{~g})$, followed by goats that kidded in winter $(406.6 \pm 32.3 \mathrm{~g})$, while the lowest yield $(326.6 \pm 26.8 \mathrm{~g})$ was recorded by goats kidded in summer.

Litter size significantly affected $(p<0.05)$ milk yield of daughters and are in agreement with the findings of Valencia et al. (2002). Mourad (1993) and Zygoyiannis and Katsaounis (1986) observed that litter size is affected only on milk yield of goats until weaning. Goats with twins produced more milk than goats with singles. Similar results were found in Zaraibi goats in Egypt (Hamed et al., 2009). This agrees with the findings of Baro et al. (1994) and Carriedo et al. (1995), who reported that multiple births in Latxa and Churra ewes resulted in higher milk yields than single births.

Multiple kidded dams were superior in milk yield compared to single kidded dams due to the stimulus provided by the suckling kids that increases production.

TDMY was significantly $(P<0.01)$ affected by season of kidding 3 . The present result was in agreement with the findings of Montaldo et al. (1982), Mukundan et al. (1983) and Valencia et al. (2002). Kala and Prakash (1990) found that season of kidding accounted for variation of milk yield in two Indian goat breeds.

The present result does not agree with the findings of Parkash and Khanna, (2005), Carriedo et al. (1995), and El-Arian et al. (2008) in different tropical and temperate breeds. Kennedy et al. (1981) studied effects of some factors on milk yield of Alpine, Saanen and Toggenburg and concluded that month of kidding affect milk yield of dams. Also, lloeje et al. (1980) reported that does kidding from January to March produced more milk than those kidding from April to July.

\section{Conclusion}

This study has shown the importance of some non-genetic factors including parity, sex of kid, litter size and season for growth performance, litter size and season of kidding on daily milk yield and age, body weight, scrotal circumference for semen characteristics which could be accounted for genetic evaluations. The non-genetic effects were very important to the growth, milk yield and semen characteristics, which need to be controlled or adjusted when comparing animals' individual productivity. These results therefore provide an important perspective on the selection objectives of Black Bengal goats by considering different environmental factors. In fact the evaluation of productive traits is generally aimed at increasing meat, milk and progeny in Black Bengal goats. 


\section{Acknowledgements}

The authors wish to acknowledge Department of Animal Breeding and Genetics; Bangladesh Agricultural University, Mymensingh for support me to conduct this study. This work was financially supported by grants from both USDA and NSICT.

\section{References}

Akhter, S., Husain, S.S., Amin, M.R. and Munzur, M. 2000. Study on the pre and post weaning growth competence of different genetic groups of Black Bengal goats. Bang. J. Anim. Sci. $29: 69-79$.

Alberio, R. 1976. Role de la photoperiode dans le developpement de la fonction de reproduction chez l'agneau lle-de-France, de la naissance a 21 mois. These de doctorat, Universite de Paris VI, Paris, France.

Al-Ghalban, A.M., Tabbaa, M.J. \& Kridli, R.T. 2004. Factors affecting semen characteristics and scrotal circumference in Damascus bucks. Small Rumin. Res. $53: 141-149$.

Amann, R.P., Seidel, G.E. and Mortimer, R.G. 2000. Fertilizing potential in vitro of semen from young beef bulls containing a high or low percentage of sperm with a proximal droplet. Theriogenology. $54: 1499-1515$.

Analla, M., Jimenez, I., Munoz, A., Serradilla, J. M. and Falagans, A. 1996. Estimation of Genetic Parameters for Milk Yield and Fat and Protein Contents of Milk from Murciano-Granadina Goats. J. Dairy Sci. 79 : 110-122.

Bailey, T.L., Monke, D., Hudson, R.S., Wolfe, D.F., Carson, R.L. and Riddell, M.G. 1996. Testicular shape and its relationship to sperm production in mature Holstein bulls. Theriogenology. $46: 881-887$.

Baro, J.A., Carriedo, J.A. and San, F. 1994. Genetic parameters of test day measures for somatic cell count, milk yield and protein percentage of milking ewes. J. Dairy Sci. $77: 2658-2662$.

Barth, A.D. and Oko, R.J. 1989. Abnormal morphology of bovine spermatozoa. lowa State University Press. Ames, lowa, USA. pp. 285-286.

Carriedo J.A., Baro J.A., Fuente L.F. and San Primitivo F. 1995. Genetic parameters for milk yield in dairy sheep. J. Anim. Breed. Genet. 112 : 59-63.

Daudu, C.S. 1984. Yankasa ram: body weight, withers height, scrotal and penis size, and sperm reserves. Int. Goat and Sheep Res. $2: 126-128$.

El-Arian, M.N., Salama, M. A. and Mohamed, A. 2008 . Estimation of genetic parameters and breeding values for growth traits on Romanov lambs in Egypt. J. Agric. Sci. 33 : 2569 - 2576.

Figueiredo, E.A.P. and Pant, K.P. 1982. Evaluation of goat breeds in the tropical northeast Brazil. An analysis of age at death in kids. Pesq. Agropec. bras. Brasilia. $17: 803-808$

Furstoss, D.P., Parks, J.E., Kaproth, M.T. and Jost, L.K. 2009. Characteristics and seasonal variations in the semen of Alpine, Saanen and Damascas goat bucks born and raised in Greece. Theriogenology. 53 : 1285-1293.

Hamed, A., Mabrouk, M. M., Shaat, I. and Bata, S. 2009. Estimation of genetic parameters and some nongenetic factors for litter size at birth and weaning and milk yield traits in zaraibi goats. Egyptian J. Sheep and Goat Sci. $4: 55-64$.

Hermiz, H.N., Al-Amily, H.J. and Assak, E.A. 1997. Some genetic and non-genetic parameters for pre-weaning growth traits in Angora goats. J. Agric. Sci. 24 : 182-186

Husain, S.S., Hors,t P. and Islam, A.B.M.M. 1996. Phenotypic selection on the improvement of growth performance of Black Bengal goats. Asian-Aust. J. Anim. Sci. $9: 149-153$

Hussain, S.S. 2004. Preservation of buck semen and their use in Artificial Insemination for rapid Genetic Improvement of Rural Goats population. Bang. J. Agric. Sci. $56: 36-45$.

Iloeje, M.U., Rounsaville, T.R., McDowell, R.E., Wiggans, G.R. and Van Vleck, L.D. 1980. Age-saison adjustment factors for Alpine, Lamancha, Nubian, Saanen and Toggenburg dairy goats. J. Dairy Sci. 63 : 1309-1316.

Kala, S.N. and Prakash, B. 1990. Genetic and phenotypic parameters of milk yield and milk composition in two Indian goat breeds. Small Rumin. Res. $3: 475-484$

Kennedy, B.W., Finley, C.M., Pollak, E.J. and Bradford, G.E., 1981. Joint effects of parity, age, and season of kidding on milk and fat yields in dairy goats. J. Dairy Sci. $64: 1707-1712$.

Khan, B.U. and Sahni, K.L. 1983. Pre-weights and linear body measurement in Jamunapari goats under semi-arid for conditions. Indian J. Anim. Sci. 53 : 385-388.

Mandiki, S.N.M., Derycke, G., Bister, J.L. and Paquay, R. 1998. Influence of season and age on sexual maturation parameters of Texel, Suffolk and Ile-de-France rams. Testicular size, semen quality and reproductive capacity. Small Rumin. Res. 28 : 67-79.

Matika, O., Wyk, J.B., Erasmus, G.J. and Baker, R.L. 2003. Genetic parameter estimates in Sabi sheep. Livest. Prod. Sci. 79 : 1728. 
Mia, M.M. and Bhuiyan, A.K.F.H. 1997. Some factors affecting birth weight of goats. Indian J. Vet. $74: 491-3$.

Mittal, J.P. 1979. A study on birth weiqht of Barbari and Jamunapari kids. Indian J. Anim. Sci. 49 : 45-47.

Montaldo, H., Rosales, J. and Juarez, A. 1982. Coeficientes de repetibilidad para algunas caracter'ısticas de producci'on de leche y reproducci 'on en cabras. Tec. Pec.M'ex. $43: 70-72$.

Mukundan, B., Khan, B.U. and Bhat, P.N. 1982. Note on growth curve in Malabari goats and their Saanen half breds. Indian J Anim. Sci. 52 : 1112-1114.

Mukundan, G. and Bhat, P.N. 1983. Lactation curve in Malabari goats and their Saanen halfbreds. Indian J. Anim. Sci. 53 : 666-669.

Osinowo, O.A., Amed, M.S. and Ekpe, G.A. 1988. Semen quality and sperm output of Yankasa rams at different ages. Theriogenology. $29: 381-386$.

Parkash, C. and Khanna, R.S. 1972. Goat production, Indian J. Anim. Prod. 2 : 10-13.

Roca, J., Martinez E., Vazquez, J.M. and Coy, P. 1992. Characteristics and seasonal variations in the semen of MurcianoGranadina goats in the Mediterranean area. Anim. Reprod. Sci. 29 : 255-262.

Rodriguez, H. 2003. Laboratory semen assessment and prediction of fertility. Reprod. Domest. Anim. 38 : $312-318$.

Salhab, S.A., Zarkawi, M., Wardeh, M.F., Al-Masri, M.R. and Kassem, R. 2003. Characterization and evaluation of semen in growing Awassi ram lambs. Trop. Anim. Health Prod. 35 : 455-463.

Singh, D.K., Singh, C.S.P. and Mishra, H.R. 1990. Birth weight of pure and crossbred kids under extensive system of management in villages. Indian J. Anim. Sci. $60: 375-377$.

Singh, D.K. and Yadava, R., 1997. Genetic studies on proportion of bone in different carcass cuts in Black Bengal and its crossbreds with Jamunapari and Beetal goats. Indian J. Anim. Sci. 67 : 996-999.

Son, Y.S. 1999. Production and uses of Korean native Black goat. Small Rumin. Res. 34 : $303-308$.

Valencia, P.M., Dobler, L.J. and Arbiza, S.I. 2002. Sources of environmental variation affecting lactation and pre-weaning growth characteristics in Saanen goats. Cuban J. Agric. Sci. 36 : 117-122.

Warmington, B.G. and Kirton, A.H. 1990. Genetic and non-genetic influences on growth and carcass traits of goats. Small Rumin. Res. 3 : 147-165.

Wilson, P.N. 1958. The effect of plane of nutrition on the growth and development of the East African dwarf goat. Part I. Effect of plane of nutrition on the live-weight gains and the external measurements of kids. J. Agric. Sci. 50: $198-210$.

Zygoyiannis, D. and Katsaounis, N. 1986. Milk yield and milk composition of indigenous goats (Capra prisca) in Greece. Anim. Prod. 42 : 365-374. 